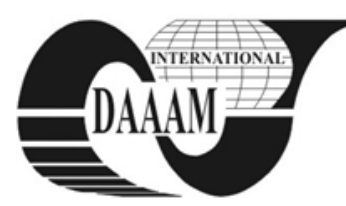

\title{
CONTRIBUTION OF INSTITUTE OF INDUSTRIAL ENGINEERING, MANAGEMENT AND QUALITY TO INITIATIVE ENTERPRISE 2020
}

\author{
DRIENIKOVA, K[atarina]; HRDINOVA, G[abriela]; NANO, T[omas]; SAKAL, P[eter] \& SYC, M[arek]
}

\begin{abstract}
The contribution deals with our contribution to strategic initiative Enterprise 2020 that's unique platform for schools, universities and commercial practice to further develop a strategic tool for sustainable global economy. The contribution to the initiative is to introduce the university subject called ,Sustainable corporate social responsibility” at Faculty of Materials Science and Technology of SUT in Trnava. Key words: sustainable development, corporate social responsibility, education, enterprise 2020.
\end{abstract}

\section{INTRODUCTION}

Sustainable development is the topic that concerns all of us, we should not ignore it but on the contrary we should try to root the thoughts of sustainable development to minds of young people at the beginning of their school life. The education to sustainable development should be implemented at least at universities. Universities besides playing an important role in sustainable development (SD) and corporate social responsibility (CSR) propagation are the institutions where the future business leaders are educated.

The paper describes new subject we want to introduce on master level at our faculty. The project KEGA, including an introduction of subject called "Sustainable corporate social responsibility", will be specialized to prepare pedagogic and R\&D employees of FMST SUT Trnava in the field of SD and CSR that will bring the improvement and extension of their theoretical knowledge and practical crafts that they can be applied and used in educational and $\mathrm{R} \& \mathrm{D}$ processes.

\section{OUR CONTRIBUTION TO INITIATIVE ENTERPRISE 2020}

Initiative of CSR Europe - Enterprise 2020 was made to solve societal challenges through collaborative action and shape the business contribution to the Europe 2020 strategy for smart, sustainable and inclusive growth. The initiative was created to support the strategy and to help to overcome the recession and prepare economy of European Union for the next decade.

Enterprise 2020 is also a unique platform for schools and universities that want to cooperate with business to champion responsible management research. The cooperation could be reflected also in developing the capacities of students and executives to be future generators of sustainable value for business and society $(* * *, 2010)$.

As at most universities in Slovakia, if not at all, there is lack of the subjects which would lead students towards sustainable development, we decided to change it and contribute to the achievement of the initiative.

We decided to introduce a new school subject called "Sustainable corporate social responsibility" within the study branch industrial management on the master level at Institute of Industrial Engineering, Management and Quality (IIEMQ) of FMST SUT in Trnava. To reach the goal we gave in project KEGA called "Implementation of the subject "Corporate Social
Responsibility Entrepreneurship" into the study program Industrial management in the second degree at MTF STU Trnava", within the third appeal called Content integration and diversification of academic study.

The major goal of the project is to introduce the subject "Sustainable corporate social responsibility" to study branch industrial management on the master level at the FMST of SUT. The partial goals of the project are:

- to process an analysis of available information resources of education to sustainable development and CSR topic,

- to suggest curriculum of the subject "Sustainable CSR",

to write teaching typescript for teaching the subject "Sustainable CSR",

to verify the quality of teaching the subject "Sustainable CSR" in experimental way,

to optimize the curriculum of the subject "Sustainable CSR" and teaching typescript according the results of the analysis.

\subsection{The current state of the topic}

Document "Baseline Study on Corporate Social Responsibility Practices in Slovakia "(2007) showed following suggestions for academic institutions: State universities should be the pioneers in the topic of CSR, they ought to rise up the consciousness and build up capacities to its implementation. Academic institutions ought to provide CSR courses at economy and management faculties at least. These institutions are responsible for preparing students who could perspectively perform prominent functions in commercial sector. As the future managers they should have enough practices with the implementation of formal CSR strategy (Gallova Kriglerova, et. al., 2007).

Every European citizen should be fitted with knowledge, practices and postures that help him to understand and solve challenges and problems of everyday modern life, regarding environmental, social, cultural and economic impacts and take global responsibility. The recession totally devalued the years of economic and social progress and revealed structural deficiencies in European economy. Meanwhile the world is quickly moving and long-time problems as globalization (***, 2005), resource press and ageing population are getting deeper. It's important to have the strategy that could contribute to be strengthen from the recession and that could make the EU economy intelligent and sustainable supporting the integration and high level of employment, productivity and social cohesion. Following documents should help to reach it: Europe 2020, Enterprise 2020, with Conclusions of European Council from 19th November 2010 about education to sustainable development (***, 2010), with UNO summit about Millennium development goals (20.-22. September 2010) and currently accepted standard ISO 26000 of corporate social responsibility. Issuing from:

holistic approach to our planet Earth as an integral system, knowing that objective reality that's rounding us has its own evolutional development which was negatively hit by human long-time acting, 
- confidence that the only alternative of humankind is the symbiosis of being in step with the nature and its regularities of development and sustainable development in all postindustrial expressions (sustainable production, sustainable consumption, sustainable marketing, sustainable profit,...),

- especially from works and opinions of A. Blazej, F. Capra, T. M. Cook, D. C. Corten, F. Gregor, H. Handerson, K.Hatiar, J. Hyrslova, L. A. Ismagilova, J. Keller, M. J. Kiernan, V. K. Lozenko, P. Stanek, W. E. Stead a J. G. Stead, D. Zadrazilova, J. Zeleny, etc .,

We want to connect the present practices and knowledge gained by solving and successful vindication of research projects solved at IIMQ FMST SUT Trnava: grant scientific project No. 1/9099/02 VEGA "Environmentally oriented management, marketing and logistics of strategic business unites"; project APVV No. 019/2001: "Transforming Industry in Slovakia Through Participatory Ergonomic"; KEGA ME SR No. 3-3111-05: "Creation of virtual robotized laboratory for supporting teaching subject "Robots and manipulators" in new accredited studying program and currently running project of the Slovak Research and Development Agency under the contract No. LPP-0384-09: "Concept HCS model 3E vs. Concept Corporate Social Responsibility (CSR) No. LPP-038409",by the project. According to :"Think globally, act locally", our teaching typescript of "Sustainable corporate social responsibility" should help to contribute to the change of paradigm to creation and sharing the wealth on our planet Earth. It's because the current state in Slovakia, Europe and also in the world is unsustainable and there's a threat of expiration of mankind and of all living on our planet Earth (Avdeev et al., 2010).

\subsection{Characteristics, description of the project}

The project would prepare pedagogic and R\&D employees of FMST SUT Trnava in the field of SD and CSR that would bring the improvement and extension of their theoretical knowledge and practical crafts that they can apply and use in educational and $R \& D$ processes.

Expected benefits of the projects:

- Better graduates' application on labor market and improvement of their employment, production and social cohesion.

- Update and enhancement of teaching process at FMST SUT Trnava in context with Strategy Europe 2020, Enterprise 2020, with Conclusions of European Council from 19th November 2010, with UNO summit about Millennium development and currently accepted standard ISO 26000 of CSR.

- Increase students' motivation.

- Increase quality of pedagogy and R\&D work of pedagogy and R\&D employees at FMST SUT in Trnava.

- Planned application of outputs of the project in social and economy practice.

Graduates of newly created subject "Sustainable CRS" will be the holders of SD and CSR thoughts capable to transform the knowledge to practice of Slovak industrial companies and step by step they would affect the change of our managers and company shareholders paradigm.

\section{Project time management process:}

1. Preliminary phase of the research: January 2012 August 2013 (Jan- Apr- to work up analysis of available information resources of the topic of education in SD and CSR; May-June- to suggest curriculum of the subject „Sustainable CSR“; June-July- to suggest research project of empiric verification of suitability, effectiveness and quality of the subject "Sustainable CSR"; July-Jan 2013 - to write first draft of educational typescript of "Sustainable CSR"; Feb- to suggest questionnaires; Mar- July - to correct the first draft of educational typescript of "Sustainable CSR" on the basis of individual reviewers' remarks; Aug- to print educational typescript).

2. Realization phase of the research: September 2013 January 2014: (Sep-Jan- experimentally to verify the suitability and the quality of the teaching process of the subject "Sustainable CSR").

3. Valuation phase of the research: February 2014 December 2014 (Feb-Mar- to evaluate the experiment results including the quality of educational typescript; Apr-May - to write report of the research, on the basis of the results to optimize the curriculum of the subject; June- to carry on workshop "Sustainable CSR"; July-Dec- to present the outputs of the research in specialized and scientific journals and also on scientific events).

\section{CONCLUSION}

To teach students to principles of sustainable development is the first - very important - step how to show them how to live in agreement with nature. Paper refers to the importance of the introduction of the subject intent on education to sustainable development. Specifically we deal with the recently submitted project KEGA called "Sustainable corporate social responsibility".

\section{ACKNOWLEDGEMENTS}

This paper was supported by the Slovak Research and Development Agency under the contract No. LPP-0384-09: "Concept HCS model 3E vs. Concept Corporate Social Responsibility (CSR)."

The paper is also a part of submitted KEGA project No. 037STU-4/2012 "Implementation of the subject "Corporate Social Responsibility Entrepreneurship" into the study program Industrial management in the second degree at MTF STU Trnava".

\section{REFERENCES}

Avdeev, S.V.; Anisimov, O. et al. (2010).Circulation of scientists noosphere wing to the world community. Available from: http://pandoraopen.ru/2010-1016/obrashhenie-uchyonyx-noosfernogo-kryla-k-mirovomusoobshhestvu/ Accessed: 2011-03-20

Gallova Kriglerova, E.; Kerestesova, Z.; Kollár, M. \&Michal Vasecka, M. (2007). Baseline Study on Corporate Social Responsibility Practices in Slovakia. Available from: http://www.partnerstva.sk/buxus/docs/UNDP_Baseline_Stu dy_CSR_SK_Slovensky.pdf Accessed: 2011-05-22

*** (2010) http://www.psqca.com.pk/News\%20Bar/attention $\% 20 I S O \% 2026000 /$ ISO_FDIS_26000_\%28E\%29.pdf International Standard. ISO/FDIS 26000. Guidance on social responsibility. Accessed on: 2011-02-10

***(2005)http://eur-lex.europa.eu/LexUriServ/ LexUriServ.do?uri=OJ:C:2006:280E:0065:0070:SK:PDF Official Journal of the European Union. C 280 E/65, Accessed on: 2010-09-12

***(2010)http://eur-lex.europa.eu/LexUriServ/ LexUriServ.do?uri=OJ:C:2010:327:0011:0014:SK:PDF. Official Journal of the European Union. C 327/11, Accessed on: 2011-04-14

***(2010)http://www.csreurope.org/data/files/enterprise2020/e nterprise2020en.pdf. - Enterprise 2020. Smart, Sustainable, Inclusive, Accessed on: 2011-03-14 